\title{
Effects of Fly Ash on Mercury Oxidation During Post Combustion Conditions
}

\author{
Annual Report \\ September 1, 1999 through August 31, 2000
}

Glenn A. Norton, Project Manager

October 2000

DOE Award No. DE-FG26-98FT40111--02

Center for Sustainable Environmental Technologies

284 Metals Development Bldg.

Iowa State University

Ames, IA 50011 


\section{DISCLAIMER}

This report was prepared as an account of work sponsored by an agency of the United States Government. Neither the United States Government nor any agency thereof, nor any of their employees, makes any warranty, express or implied, or assumes any legal liability or responsibility for the accuracy, completeness, or usefulness of any information, apparatus, product, or process disclosed, or represents that its use would not infringe privately owned rights. Reference herein to any specific commercial product, process, or service by trade name, trademark, manufacturer, or otherwise does not necessarily constitute or imply its endorsement, recommendation, or favoring by the United States Government or any agency thereof. The views and opinions of authors expressed herein do not necessarily state or reflect those of the United States Government or any agency thereof. 


\begin{abstract}
Tests were performed in simulated flue gas streams using two fly ash samples from the electrostatic precipitators of two full-scale utility boilers. One fly ash was derived from a Powder River Basin (PRB) coal, while the other was derived from Blacksville coal (Pittsburgh No. 8 seam). The tests were performed at temperatures of 120 and $180^{\circ} \mathrm{C}$ under different gas compositions using whole fly ash samples as well as magnetic and nonmagnetic concentrates from sized fly ash. Only the Blacksville ash contained magnetic phases. The whole and fractionated fly ash samples were analyzed for morphology, chemical composition, mineralogical composition, total organic carbon, porosity, and surface area. Mineralogically, the Blacksville ash was composed predominantly of magnetite, hematite, quartz, and mullite, while the PRB ash contained mostly quartz with lesser amounts of lime, periclase, and calcium aluminum oxide. The iron oxides in the Blacksville ash were concentrated almost entirely in the largest size fraction. As anticipated, there was not a clean separation of magnetic (Fe-rich) and nonmagnetic (aluminosilicate-rich) phases for the Blacksville ash. The Blacksville ash had a significantly higher surface area and a much higher unburned carbon content than the PRB ash.

Elemental mercury $(\mathrm{Hg})$ streams were injected into the simulated flue gas and passed over filters (housed in a convection oven) loaded with fly ash. Concentrations of total, oxidized, and elemental $\mathrm{Hg}$ downstream from the ash samples were determined by the Ontario Hydro Method. The gas stream composition and whether or not ash was present in the gas stream were the two most important variables. Based on the statistical analyses, the presence of $\mathrm{HCl}, \mathrm{NO}$, $\mathrm{NO}_{2}$, and $\mathrm{SO}_{2}$ and all two-way gas interactions were significant. In addition, it appears that even four-factor interactions between those gases are significant. The $\mathrm{HCl}, \mathrm{NO}_{2}$, and $\mathrm{SO}_{2}$ were critical gases resulting in $\mathrm{Hg}$ oxidation, while the presence of $\mathrm{NO}$ appeared to suppress oxidation. The Blacksville fly ash tended to show slightly more catalytic activity than the PRB fly ash, but this could be largely due to the higher surface area of the Blacksville ash. Temperature was not a statistically important factor. The magnetic (Fe-rich) phases did not appear to be more catalytically active than the nonmagnetic phases, and unburned carbon did not appear to play a critical role in oxidation chemistry.
\end{abstract}




\section{TABLE OF CONTENTS}

$\underline{\text { Page }}$

Executive Summary $\quad 1$

Introduction 3

$\begin{array}{ll}\text { Experimental } & 4\end{array}$

$\begin{array}{ll}\text { Results and Discussion } & 9\end{array}$

$\begin{array}{lr}\text { Conclusions } & 18\end{array}$

$\begin{array}{lr}\text { Future Work } & 18\end{array}$

$\begin{array}{ll}\text { References } & 19\end{array}$

$\begin{array}{ll}\text { Acknowledgements } & 21\end{array}$ 


\section{EXECUTIVE SUMMARY}

Mercury $(\mathrm{Hg})$ is listed as a hazardous air pollutant (HAP) in the 1990 Amendments to the Clean Air Act. Coal-fired power generation emits roughly 50 tons of $\mathrm{Hg}$ annually and may be regulated in the near future. Relative concentrations of different $\mathrm{Hg}$ species in coal combustion effluents are highly variable, and this greatly affects $\mathrm{Hg}$ removal efficiencies by pollution control technologies. However, because the chemistry affecting the $\mathrm{Hg}$ speciation in effluents from coal utilization is poorly understood, it is difficult to predict $\mathrm{Hg}$ removal efficiencies for any given $\mathrm{Hg}$ abatement technology. In order to better control $\mathrm{Hg}$ in these gas streams, a basic understanding of the $\mathrm{Hg}$ chemistry in coal combustion streams is necessary. This work focuses on the effects of fly ash on $\mathrm{Hg}$ chemistry in flue gas streams, which will hopefully allow more accurate predictions to be made about the $\mathrm{Hg}$ speciation in gas streams from coal-fired boilers.

A bench-scale apparatus was used to simulate flue gas streams using humidified blends of $\mathrm{CO}, \mathrm{CO}_{2}, \mathrm{HCl}, \mathrm{Hg}, \mathrm{NO}, \mathrm{NO}_{2}, \mathrm{O}_{2}, \mathrm{SO}_{2}$, and $\mathrm{N}_{2}$. Tests were performed using two fly ash samples from the electrostatic precipitators (ESPs) of two full-scale utility boilers. One fly ash was derived from a Powder River Basin (PRB) coal, while the other was derived from Blacksville coal (Pittsburgh No. 8 seam). The whole and fractionated fly ash samples were analyzed for morphology, chemical composition, mineralogical composition, total organic carbon, porosity, and surface area. Fly ash samples were loaded onto quartz fiber filters and housed in a convection oven. Fresh portions of fly ash were used for each test. Samples that were tested included 1) whole Blacksville and PRB fly ash, 2) magnetic and nonmagnetic concentrates from the whole fly ash, 3) two size fractions of each fly ash, and 4) magnetic and nonmagnetic concentrates from the sized fly ash. Only the Blacksville ash contained magnetic phases, and those phases were present almost entirely in the largest size fraction. Continuous streams of elemental $\mathrm{Hg}$ were passed over the fly ash in the presence of different gas blends at temperatures of 120 or $180^{\circ} \mathrm{C}$ for 75 minutes. Concentrations of total, oxidized, and elemental $\mathrm{Hg}$ downstream from the ash samples were determined by the Ontario Hydro Method. Retention of $\mathrm{Hg}$ on the loaded filters was negligible, and the experimental repeatability in the Ontario Hydro results was generally very good. Statistical analyses were performed on the data obtained with the whole fly ash samples by fitting a full factorial model to the analytical data via least squares regression analysis.

The fly ash samples consisted predominantly of highly spherical particles, which is typical for coal combustion fly ash. However, in the largest size fraction, the Blacksville ash was substantially less homogeneous and contained more porous and irregularly shaped particles than the PRB fly ash. As anticipated, there was not a clean separation of magnetic (Fe-rich) and nonmagnetic (aluminosilicate-rich) phases for the Blacksville ash. The magnetic Blacksville ash contained about $25 \%$ (atomic) Fe, while the nonmagnetic phases contained about $4 \% \mathrm{Fe}$. The magnetic phases still contained a significant amount (about 10\% each) of $\mathrm{Al}$ and Si. There were no substantial differences in the chemical or mineralogical composition of the two Blacksville fly ash sizes studied, with the exception that the iron oxides were concentrated almost entirely in the largest size fraction. Mineralogically, the Blacksville ash was composed predominantly of magnetite, hematite, quartz, and mullite. The PRB fly ash contained only a few percent Fe and contained no detectable Fe-bearing minerals. The mineral components in that ash were primarily quartz, with lesser amounts of lime, periclase, and calcium aluminum oxide. 


\section{EXECUTIVE SUMMARY (CONT.)}

The surface area of the Blacksville fly ash was significantly higher than that of the PRB fly ash. For the Blacksville ash, the surface area of the nonmagnetic phases was substantially higher than that of the magnetic phases. The Blacksville ash contained about 3.6\% unburned carbon, which was concentrated almost entirely in the nonmagnetic fraction of the largest size fraction studied. The PRB fly ash contained less than $0.1 \%$ unburned carbon.

Results from the Ontario Hydro tests indicated that the most important variables were the gas stream composition and whether or not ash was present in the gas stream. The source of the ash also affected the results, but to a lesser extent. Although no major differences in catalytic activity were observed between the two fly ash samples studied, the Blacksville fly ash did tend to show more catalytic activity than the PRB fly ash. However, this could be largely due to the higher surface area of the Blacksville ash. Temperature was not a statistically important factor for the two temperatures tested. The magnetic (Fe-rich) phases did not appear to be more catalytically active than the nonmagnetic phases in our work. Also, based on very limited data, the unburned carbon did not appear to play a critical role in oxidation chemistry.

For the gases used, $\mathrm{HCl}, \mathrm{NO}, \mathrm{NO}_{2}$, and $\mathrm{SO}_{2}$ were the most important gases associated with $\mathrm{Hg}$ oxidation. Statistical analyses of the data obtained using whole fly ash samples indicated that the most important gas was $\mathrm{NO}_{2}$, followed by $\mathrm{NO}$ and $\mathrm{HCl}$. However, the effect of $\mathrm{NO}$ depended on whether $\mathrm{NO}_{2}$ was present or not. $\mathrm{SO}_{2}$ was also important as a main factor, but was more important in its interaction with other gas components. Based on the statistical analyses, all factors (i.e., gases) and two-way gas interactions were significant. In addition, it appears that even four-factor (the four gases noted above) interactions are significant.

For the sized Blacksville fly ash exposed to various gas blends at $180^{\circ} \mathrm{C}$, using the nonmagnetic phases from the first cyclone catch always (for each gas blend tested) resulted in a greater degree of $\mathrm{Hg}$ oxidation than the magnetic phases from the same size fraction. This may be partially attributable to the fact that the nonmagnetic phases had a higher surface area that the magnetic phases. However, the differences in the amount of oxidized $\mathrm{Hg}$ produced for magnetic and nonmagnetic concentrates from the first cyclone (largest sizes) catch were generally not substantial. The second size fraction of the Blacksville ash did not contain any magnetic material. When the nonmagnetic phases from the first and second size fractions were exposed to various gas blends, more oxidized $\mathrm{Hg}$ was generally produced by the smaller particle sizes. This is to be expected based on the fact that the smaller size fraction had a higher surface area. In all cases, somewhat anomalous data were obtained when only $\mathrm{NO}_{2}$ and $\mathrm{HCl}$ were added to the baseline blend. 


\section{INTRODUCTION}

Mercury (Hg) is listed as a hazardous air pollutant (HAP) in the 1990 Amendments to the Clean Air Act. Coal-fired power generation emits on the order of 50 tons of $\mathrm{Hg}$ annually (1) and accounts for about a third of the total annual anthropogenic $\mathrm{Hg}$ emissions in the U.S. (2). In view of concerns over health and environmental impacts related to $\mathrm{Hg}$, the $\mathrm{Hg}$ emissions from coal-fired power plants may be regulated in the near future. The relative concentrations of different $\mathrm{Hg}$ species present in coal combustion effluents are highly variable, and this is a major factor affecting $\mathrm{Hg}$ removal efficiencies by various conventional (e.g., wet scrubbers) and experimental (e.g., activated carbon injection) pollution control technologies. Unfortunately, the chemistry affecting the $\mathrm{Hg}$ speciation in effluents from coal utilization is poorly understood. Consequently, it is currently impossible to predict $\mathrm{Hg}$ removal efficiencies for any given $\mathrm{Hg}$ abatement technology (3). In order to better control $\mathrm{Hg}$ in these gas streams, a basic understanding of the chemistry of $\mathrm{Hg}$ under a range of thermal and chemical conditions is necessary.

It has recently become suspected that fly ash (e.g., fly ash from Blacksville coal) can play an important role in $\mathrm{Hg}$ chemistry by catalytically oxidizing some of the elemental $\mathrm{Hg}$ in the gas stream (4). However, the mechanisms by which fly ash affects the distribution of $\mathrm{Hg}$ species are unknown. The unburned carbon in fly ash is one important variable that has not been adequately addressed, and it could potentially be involved in the $\mathrm{Hg}$ oxidation mechanisms (5). A number of studies with activated carbon sorbents are also relevant to our work. For example, it appears that $\mathrm{NO}_{2}$ may cause oxidation and desorption of $\mathrm{Hg}$ from activated carbon sorbents (6). In another study, activated carbon catalysts oxidized $95-100 \%$ of the elemental $\mathrm{Hg}$ in both simulated and actual flue gas streams from coal-fired combustors (7). Also, there appears to be substantial interactions between $\mathrm{SO}_{2}$ and $\mathrm{NO}_{2}$ with carbon-based sorbents, which results in rapid breakthrough of $\mathrm{Hg}$ and conversion of the $\mathrm{Hg}$ to an oxidized form (8). The unburned carbon in fly ash may result in similar oxidation mechanisms.

In other work, it was found that $40 \%$ of the elemental $\mathrm{Hg}$ (present at $40 \mathrm{ppb}$ ) in a stream of $\mathrm{NO}, \mathrm{O}_{2}$, and $\mathrm{CO}_{2}$ was oxidized in the presence of either $\mathrm{Al}_{2} \mathrm{O}_{3}$ or $\mathrm{SiO}_{2}$, while there was virtually no oxidation of the $\mathrm{Hg}$ when $\mathrm{SO}_{2}$ was also present (9). When using a mixture of $\mathrm{Ab}_{2} \mathrm{O}_{3}$, $\mathrm{SiO}_{2}$, and $\mathrm{Fe}_{2} \mathrm{O}_{3}$, at least $80 \%$ of the $\mathrm{Hg}$ was oxidized, regardless of whether $\mathrm{SO}_{2}$ was present. Thus, the inorganic components of fly ash require examination as well.

The $\mathrm{HCl}$ content of the flue gas is another important variable related to the distribution of gaseous $\mathrm{Hg}$ species, since coals high in chlorine generally appear to have more oxidized $\mathrm{Hg}$ in the flue gas than coals low in chlorine $(10,11)$. Although the presence of $\mathrm{HCl}$ has been linked to the oxidation of $\mathrm{Hg}$, the role of $\mathrm{HCl}$ and the specific reaction pathways are not completely understood (12). There are indications that the low-temperature oxidation of $\mathrm{Hg}$ is driven by the reaction of elemental $\mathrm{Hg}$ with $\mathrm{Ch}$, where the $\mathrm{Ch}_{2}$ is generated by catalytic reactions between $\mathrm{HCl}$ and char or other ash components (13). Equilibrium calculations on the relative percentages of elemental and oxidized $\mathrm{Hg}$ species have not been supported by field data, and the equilibrium seems to "freeze" prematurely for unknown reasons (5). Because the oxidation of $\mathrm{Hg}$ in the presence of $\mathrm{HCl}$ is slow and proceeds only at high temperatures and high $\mathrm{HCl}$ concentrations, it 
is likely that the low temperature oxidation of $\mathrm{Hg}$ is catalyzed by metals in fly ash in the presence of $\mathrm{HCl}$ and/or $\mathrm{NO}_{\mathrm{x}}(9)$.

The goal of this research is to provide fundamental information on post-combustion flue gas chemistry that will help predict $\mathrm{Hg}$ speciation in gas streams from coal-fired boilers. This will be accomplished through an improved understanding of the role of fly ash on $\mathrm{Hg}$ chemistry. A substantial amount of information will also be obtained on the role of various gases in determining the distribution of gaseous $\mathrm{Hg}$ species in flue gas streams. For example, the effects of $\mathrm{NO}_{\mathrm{x}} / \mathrm{HCl}$ blends are being studied because of the suspected synergistic effects between those gases (14). Bench-scale tests with simulated flue gas streams and laboratory-scale combustion tests will be used to study the chemistry of $\mathrm{Hg}$ speciation using rigidly controlled experimental parameters. Fly ash samples will be exposed to both simulated and actual flue gas streams under a range of thermal conditions and flue gas compositions. Results from these tests will yield important information related to the chemistry associated with the oxidative conversion of $\mathrm{Hg}$ by fly ash, and chemical reaction pathways related to $\mathrm{Hg}$ speciation will be postulated. This will in turn lead to more accurate predictions on $\mathrm{Hg}$ removal efficiencies using both conventional and experimental $\mathrm{Hg}$ abatement technologies.

\section{EXPERIMENTAL}

\section{Fly Ash Samples}

Testing was performed with fly ash samples from the electrostatic precipitators (ESP) of two full-scale utility boilers. One fly ash sample was obtained from a 65-MW front-fired pulverized coal boiler rated at 620,000 lbs steam/hr at the Ames Municipal Power Plant (Ames, Iowa) while burning Wyodak-Anderson coal (subbituminous coal from the North Antelope Mine, Campbell County, Powder River Basin, Wyoming). That boiler is equipped with a hotside ESP. The Powder River Basin (PRB) fly ash was collected while the boiler was at $90 \%$ of maximum load. The other fly ash was obtained from a 150-MW tangentially-fired pulverized coal boiler rated at 1,200,000 lbs steam/hr at the AES Cayuga Plant (near Lansing, New York) while burning Pittsburgh No. 8 coal (bituminous coal from the Blacksville \#2 Mine, Blacksville, WV). That unit is equipped with a cold-side ESP. The Blacksville fly ash, was collected while the boiler was at $85-100 \%$ of capacity. These fly ash samples were selected because of previous observations with similar ashes. For example, when Blacksville coal was burned at one site, over $80 \%$ of the $\mathrm{Hg}$ in the flue gas was observed to be in the oxidized form, which was believed to be partially due to the catalytic oxidation of $\mathrm{Hg}$ by the fly ash (15). The effects of fly ash on $\mathrm{Hg}$ speciation was less pronounced when firing two western coals that were tested.

In some of the tests with the Blacksville fly ash, magnetic and nonmagnetic concentrates from the whole (unfractionated) fly ash were exposed to simulated flue gas streams. The PRB fly ash did not contain any highly magnetic fly ash components. The magnetic concentrates from the Blacksville ash were obtained by putting a thin layer of ash in a covered glass petri dish. A hand magnet was placed directly on top of the glass lid and moved around randomly. This picked up only the magnetic ash. The side of the petri dish was tapped periodically to dislodge ash particles that were only weakly or moderately magnetic. This resulted in the 
retention of only the strongly magnetic ash fraction, which comprised $20 \%$ of the ash sample. Next, the cover of the petri dish was removed and the magnet was placed directly into the ash in the petri dish to remove essentially all particles with any significant degree of magnetism. The ash remaining in the petri dish constituted the nonmagnetic fraction, which comprised $46 \%$ of the ash sample. For testing in simulated flue gas streams, only the strongly magnetic ash and the nonmagnetic ash were used. This provided the most diversity in the mineralogical composition of the ash samples exposed to simulated flue gas streams.

In addition to obtaining magnetic and nonmagnetic concentrates from the whole Blacksville fly ash, the Blacksville and PRB fly ashes were sized using a high-volume Source Assessment Sampling System containing a series of three cyclones to provide nominal cutoff diameters of 10, 3, and 1 microns for the first, second, and third cyclones, respectively. The first, second, and third cyclones collected $85-90 \%, 10-15 \%$, and about $1 \%$ of the total ash, respectively. Since the smallest cyclone contained only $1 \%$ or less of the total ash sample, only the ash samples from the first two cyclone catches were used for testing purposes. For the sized Blacksville fly ash, the ash collected in the first cyclone was magnetically separated as discussed above. The catch in the second cyclone for the Blacksville fly ash contained no strongly magnetic phases. The sized PRB fly ash was not magnetically separated because, as noted above, it did not contain any strongly magnetic phases.

\section{Coal Samples}

About 1 1/2 tons each of Blacksville and PRB coals were obtained and are ready for use. The raw coal samples have a top size of roughly two inches. Prior to combustion, the coal is ground to about $40 \%$ minus 200 mesh ( 75 microns). Test burns with the PRB coal have been successfully completed, and sustained combustion could easily be achieved without the use of auxiliary fuels.

\section{Testing Apparatus}

A bench-scale testing apparatus was constructed to simulate flue gas streams from coalfired power plants and to evaluate the potential for fly ash to oxidize elemental $\mathrm{Hg}$ in those streams. The bench-scale apparatus consists of a stainless steel mixing manifold, a gas humidification system, a convection oven for heating the fly ash to the desired temperatures, a series of impingers with absorbing solutions for collecting and speciating $\mathrm{Hg}$, and a dry gas meter. The sample line carrying blended gases downstream from the manifold is constructed of PTFE Teflon. With the exception of $\mathrm{HCl}$ and $\mathrm{Hg}$, gases were introduced into the manifold and blended at that point. The $\mathrm{HCl}$ and $\mathrm{Hg}$ were introduced downstream from the manifold via Teflon union tees in the sample transport line. For $\mathrm{HCl}$ and $\mathrm{Hg}$, all sample transport lines prior to the mixing tees were made of Teflon as well. The gas manifold and all sample transport lines downstream from the manifold were heated to $175^{\circ} \mathrm{C}$. From the manifold, the gases were transported directly to the convection oven containing the filters loaded with fly ash. The filters were housed in Method 5 type filter holders with Teflon filter supports. The gases exiting the oven were immediately passed into impinger solutions to collect and speciate $\mathrm{Hg}$.

Nominal concentrations of the gases used in the simulated flue gas matrix are shown in Table 1. Gases in the flue gas matrix were metered individually and included $\mathrm{CO}, \mathrm{CO}_{2}, \mathrm{HCl}$, 
$\mathrm{NO}, \mathrm{NO}_{2}, \mathrm{O}_{2}, \mathrm{SO}_{2}$, and $\mathrm{N}_{2}$. Compressed gas cylinders were used for those gases. A certified elemental $\mathrm{Hg}$ permeation tube from VICI Metronics was used to generate the elemental $\mathrm{Hg}$ vapor. The permeation tube was housed in a glass U-tube, which was heated in a covered water bath. A stream of nitrogen flowing at $200 \mathrm{~mL} / \mathrm{min}$ continuously passed over the permeation tube and transported the evolved $\mathrm{Hg}$ to the main sample line, where it was introduced through a Teflon mixing tee. For each test run, roughly 13,000 ng (nominal) of $\mathrm{Hg}$ were passed through the system. A solenoid diaphragm pump was used to add moisture to the gas stream by pumping water at a very precise rate into a stainless steel coil immersed in a hot oil bath in a metal can. A stream of nitrogen flowing at $2 \mathrm{~L} / \mathrm{min}$ carried the steam into the primary gas stream.

Table 1. Concentrations of Individual Gases Used in the Simulated Flue Gas Streams.

\begin{tabular}{|l|c|}
\hline GAS & CONCENTRATION IN \\
& FINAL GAS STREAM \\
\hline $\mathbf{C O}$ & $100 \mathrm{ppm}$ \\
$\mathbf{C O}$ & $12 \%$ \\
$\mathbf{H C l}$ & $50 \mathrm{ppm}$ \\
$\mathbf{H g}$ & $12 \mu \mathrm{g} / \mathrm{m}^{3}$ \\
$\mathbf{H}_{2} \mathbf{O}$ & $10 \%$ \\
$\mathbf{N O}$ & $300 \mathrm{ppm}$ \\
$\mathbf{N O}_{2}$ & $20 \mathrm{ppm}$ \\
$\mathbf{O}_{2}$ & $6 \%$ \\
$\mathbf{S O}_{2}$ & $1600 \mathrm{ppm}$ \\
$\mathbf{N}_{2}$ & Balance \\
\hline
\end{tabular}

\section{Testing Approach}

Fly ash samples were loaded onto Whatman 9-cm QMA quartz microfiber filters using a Method 5 type filter holder connected to a section of 1/8-inch OD stainless steel tubing. The downstream side of the filter holder was connected to a small vacuum pump. For each test, $0.6 \mathrm{~g}$ of ash were spread out into a thin layer on a clean, flat surface and the ash was suctioned up into the filter holder at a gas flow rate of $15 \mathrm{~L} / \mathrm{min}$. This gave an ash loading of $10 \mathrm{mg} / \mathrm{cm}^{2}$. Other gas flow rates and sample loadings were tested, and this procedure was selected since it appeared to give the most even ash loading.

A continuous stream of elemental $\mathrm{Hg}$ was passed over the fly ash samples in the presence of different gas blends at a total gas flow rate of $15 \mathrm{~L} / \mathrm{min}$ (dry) for a period of 75 minutes. All tests were performed in duplicate on the same day, and fresh portions of fly ash were used for each test. Concentrations of total $\mathrm{Hg}$, elemental $\mathrm{Hg}$, and oxidized $\mathrm{Hg}$ downstream from the ash samples were determined using the Ontario Hydro Method (16), which is known to require considerable experience and training (17). The method involves using a series of eight impingers. The first three impingers contain $\mathrm{KCl}$ absorbing solutions to preferentially collect oxidized $\mathrm{Hg}$. The $\mathrm{KCl}$ impingers are followed by an impinger containing an aqueous mixture of $\mathrm{HNO}_{3}$ and $\mathrm{H}_{2} \mathrm{O}_{2}$ to remove $\mathrm{SO}_{2}$ and other unwanted gaseous compounds. That impinger is followed by a series of three impingers containing $\mathrm{H}_{2} \mathrm{SO}_{4} / \mathrm{KMnO}_{4}$ absorbing solutions to collect 
elemental $\mathrm{Hg}$. The final impinger contains silica gel desiccant to dry the gases before entering the dry gas meter.

In addition to using the full blend (shown in Table 1), some tests were performed using only a "baseline blend" consisting of $\mathrm{CO}, \mathrm{CO}_{2}, \mathrm{Hg}, \mathrm{N}_{2}, \mathrm{O}_{2}$, and $\mathrm{H}_{2} \mathrm{O}$. The baseline blend was considered to be nonreactive. Other tests involved adding specific reactive gases $(\mathrm{HCl}, \mathrm{NO}$, $\mathrm{NO}_{2}$, and $\mathrm{SO}_{2}$ ) or combinations of reactive gases to the baseline blend. A total gas flow rate of $15 \mathrm{~L} / \mathrm{min}\left(32 \mathrm{ft}^{3} / \mathrm{hr}\right)$ was used for the tests. When some of the gases in the simulated flue gas were eliminated to provide the desired matrix for specific tests, the flow of the $\mathrm{N}_{2}$ balance gas was increased accordingly to maintain the $15 \mathrm{~L} / \mathrm{min}$ (dry) nominal flow rate.

Tests were initially performed with unsized PRB and Blacksville fly ash samples using both the "baseline blend" and the full gas blend. Those tests were performed at both 120 and $180^{\circ} \mathrm{C}$. As a reference point and a quality control measure, tests were also performed using the full gas blend with blank filters. In addition, a limited number of tests were performed whereby magnetic and nonmagnetic concentrates from the unsized Blacksville fly ash were exposed to the full gas blend at $180^{\circ} \mathrm{C}$.

Other tests were performed with the whole Blacksville fly ash at $180^{\circ} \mathrm{C}$ using a full factorial design whereby individual gases or combinations of gases were either present or absent in the gas blend. Results of those tests indicated that the most reactive mixture was when $\mathrm{NO}_{2}$, $\mathrm{SO}_{2}$, and $\mathrm{HCl}$ were added to the baseline blend. Based on those results, subsequent tests were performed with that gas matrix at $180^{\circ} \mathrm{C}$ using sized (first and second cyclone catches only) PRB and Blacksville fly ash as well as magnetic and nonmagnetic concentrates from the sized fly ash. With regard to the magnetic and nonmagnetic concentrates, it must be emphasized once again that the PRB fly ash did not contain any highly magnetic material, so no magnetic concentrates were available for that ash. Similarly, magnetic concentrates for the sized Blacksville ash were not available for the second cyclone catch. For the Blacksville fly ash, the different ash fractions were also exposed to various gas combinations (added to the baseline blend) at $180^{\circ} \mathrm{C}$, including 1) $\mathrm{NO}_{2}$ alone, 2) $\left.\mathrm{NO}_{2}+\mathrm{HCl}, 3\right) \mathrm{NO}_{2}+\mathrm{SO}_{2}$, and 4) $\mathrm{NO}_{2}+\mathrm{SO}_{2}+\mathrm{HCl}$.

\section{$\underline{\text { Sample Analyses }}$}

Scanning electron microscopy with energy-dispersive x-ray analysis (SEM-EDX) was used to examine the morphology and chemical composition of the fly ash samples. Specifically, a Hitachi S-2460N SEM was coupled to an Oxford Instruments Isis Model 200 x-ray analyzer. This technique does not provide bulk ash composition since the sampling depth is on the order of 1 to $2 \mu \mathrm{m}$. Nonetheless, it does provide some valuable chemical information on the samples. Elemental scans were taken at low magnification to provide overall chemical concentrations. The chemical data are considered to be semiquantitative, but are believed to be accurate to within about $20 \%$. For a given element, the relative concentrations observed between samples are considered accurate.

X-ray diffraction (XRD) was used to examine the mineralogical composition of the whole and fractionated fly ash samples. The scans were performed using a Siemens D500 x-ray diffractometer with $\mathrm{Cu} \mathrm{K}-\alpha$ radiation. For the XRD analyses, it is important to note that XRD 
identifies only crystalline components of the sample. This is important since coal combustion fly ash typically contains a considerable amount of glassy material.

BET measurements (using $\mathrm{N}_{2}$ adsorption isotherms) were obtained on whole and fractionated fly ash samples with a Micromeritics Instrument Corporation Accelerated Surface Area Porosimeter 2010. The surface area (both external and micropore), pore volume, and average pore diameter were determined.

Total organic carbon (TOC), or unburned carbon, was determined in the bulk fly ash samples using a Perkin Elmer TGA 7 Thermogravimetric Analyzer with a TAC 7/DX controller. About $25 \mathrm{mg}$ of ash were heated to $750^{\circ} \mathrm{C}$ at a rate of $20^{\circ} \mathrm{C} / \mathrm{min}$ in nitrogen. The sample was held at that temperature until a constant weight was obtained, which took about 30 minutes. The gas stream was then switched to air while maintaining a temperature of $750^{\circ} \mathrm{C}$. The weight loss observed in the presence of air was measured, which constituted the TOC content of the sample.

The impinger solutions from the Ontario Hydro sampling train were analyzed for $\mathrm{Hg}$ to determine the total amount of $\mathrm{Hg}$ collected and the percentages of elemental and oxidized $\mathrm{Hg}$. Solutions were prepared for analysis using procedures specified in the Ontario Hydro Method. Analyses for $\mathrm{Hg}$ in the impinger solutions were performed by conventional flow-injection cold vapor atomic absorption spectroscopy using a Leeman Labs PS200II Mercury Analysis System.

\section{$\underline{\text { Statistical Analysis of Data }}$}

Statistical analyses were performed on the data obtained for the whole fly ash samples (statistical analyses for tests with the fractionated fly ash samples are pending). All conclusions are based on statistical analyses performed at the $90 \%$ confidence level. Three series of analyses (shown in Table 2) were completed. The approach used for the statistical analysis was to fit a full factorial model to the analytical data via least squares regression analysis. The factor levels were coded to lie in the range of -1 (factor at its low level) to +1 (factor at its high level). The statistical data were used to derive "main effects" plots to show what happens on average to the response when each one of the factors is changed from its low level to its high level. Because averages can be misleading, interaction plots were used to amplify main effects. This was done since the effect of one factor often depends, in general, upon the value (level) of the others.

Table 2. Variables for Statistical Analysis of Data Obtained with the Whole Fly Ash Samples.

Test Series 1

Ash Type (PRB vs. Blacksville)

Ash Included (Ash vs. No Ash)

Temperature $\left(120^{\circ}\right.$ vs. $\left.180^{\circ} \mathrm{C}\right)$

\section{Test Series 2}

Ash Type (PRB vs. Blacksville)

Temperature $\left(120^{\circ}\right.$ vs. $\left.180^{\circ} \mathrm{C}\right)$

Gas Composition (Baseline vs. Full Blend)

\section{Test Series 3}

$\mathrm{SO}_{2}$ (0 vs. 1600 ppm)

NO (0 vs. 300 ppm)

$\mathrm{NO}_{2}$ (0 vs. 20 ppm)

$\mathrm{HCl}$ (0 vs. 50 ppm) 


\section{RESULTS AND DISCUSSION}

\section{$\underline{\text { Fly Ash Characterization }}$}

In terms of particle morphology, the samples had the typical fly ash morphology and consisted predominantly of highly spherical particles. However, for the ash collected in the first cyclone, the Blacksville fly ash was substantially less homogeneous and contained more porous and irregularly shaped particles than the PRB fly ash. Differences between the two fly ashes were less pronounced for the catches from the second cyclone.

The SEM-EDX analyses of the Blacksville fly ash indicated that the Fe-rich (highly magnetic) phases in the first cyclone catch contained roughly $25 \%$ (atomic) $\mathrm{Fe}$, about $10 \%$ each of $\mathrm{Al}$ and $\mathrm{Si}$, about $2 \% \mathrm{Ca}$, and lesser amounts of $\mathrm{Na}, \mathrm{S}, \mathrm{K}$, and $\mathrm{Ti}$. It is not surprising that the magnetic fraction has a significant amount of $\mathrm{Al}$ and $\mathrm{Si}$. There is never a complete separation of iron oxides and aluminosilicate material due to particle cohesion during the separation process. Also, significant amounts of $\mathrm{Fe}$ are typically dissolved (atomic substitutions) in a glassy aluminosilicate matrix. The nonmagnetic Blacksville fly ash fraction in the first cyclone catch contained only about $4 \%$ (atomic) Fe, $10 \% \mathrm{Al}$, and $20 \% \mathrm{Si}$. As with the magnetic ash, the nonmagnetic ash fraction also contained about $2 \% \mathrm{Ca}$ with lesser amounts of $\mathrm{Na}, \mathrm{S}, \mathrm{K}$, and Ti. The fly ash from the second cyclone catch (all nonmagnetic) was very similar in composition to the nonmagnetic fraction in the ash from the first cyclone catch. For the PRB fly ash (all nonmagnetic), the ash from the first and second cyclones contained about 3\% (atomic) Fe, 10$20 \% \mathrm{Al}$ and $\mathrm{Si}$, about $10 \% \mathrm{Ca}$, and $2 \%$ or less of $\mathrm{Mg}, \mathrm{S}, \mathrm{K}$, and $\mathrm{Ti}$. The first cyclone catch was enriched in $\mathrm{Si}$ relative to $\mathrm{Al}$, while the second cyclone catch contained equimolar amounts of $\mathrm{Si}$ and $\mathrm{Al}$.

For the Blacksville fly ash, XRD results indicated that the whole ash contained primarily quartz $\left(\mathrm{SiO}_{2}\right)$, mullite $\left(\mathrm{Al}_{6} \mathrm{Si}_{2} \mathrm{O}_{13}\right)$, magnetite $\left(\mathrm{Fe}_{3} \mathrm{O}_{4}\right)$, hematite $\left(\mathrm{Fe}_{2} \mathrm{O}_{3}\right)$, a trace of lime $(\mathrm{CaO})$, and possibly a trace of anhydrite $\left(\mathrm{CaSO}_{4}\right)$. The magnetic concentrate from the first cyclone catch of the sized ash contained the same minerals as noted for the whole ash, except for lime and anhydrite. As expected, there was a clear enrichment in the iron oxides relative to the quartz and mullite phases. The nonmagnetic phases from the first cyclone catch contained the same minerals noted for the whole ash, but with an increased amount of lime. As expected, the nonmagnetic phases were enriched in quartz and mullite relative to the iron oxides. The fly ash from the second cyclone (all nonmagnetic) was very similar in mineralogical composition to the nonmagnetic ash from the first cyclone, although no lime was detected in this fraction. A substantial amount of amorphous (noncrystalline) material was evident in the ash collected in the second cyclone.

The PRB fly ash contained mostly quartz with lesser amounts of lime, periclase $(\mathrm{MgO})$, calcium aluminum oxide $\left(\mathrm{Ca}_{3} \mathrm{Al}_{2} \mathrm{O}_{6}\right)$, and possibly a trace of anhydrite. No magnetite or hematite was detected. The sized fly ash in the first cyclone (all nonmagnetic) was very similar in composition to the whole ash in terms of mineralogy. The ash from the second cyclone (all nonmagnetic) was considerably different from that in the first cyclone in that it had substantially 
more amorphous material and relatively little quartz relative to the amounts of anhydrite, lime, periclase, and calcium aluminum oxide.

BET surface areas and the organic carbon contents of the whole and fractionated fly ashes are shown in Table 3. The surface area of the whole Blacksville fly ash was significantly higher than that of the PRB fly ash, and the surface area of the highly magnetic Blacksville fly ash in the first cyclone was substantially lower than the nonmagnetic phases in that cyclone fraction. Similarly, the fly ash from the second cyclone catch was substantially higher in surface area for the Blacksville fly ash as opposed to the PRB fly ash. For each whole fly ash sample, the BET measurements showed about $70 \%$ of the total surface area was classified as external surface area, with the remainder classified as micropore surface area. The BET average pore diameter was $54 \AA$ for the whole Blacksville fly ash and was $64 \AA$ for the whole PRB fly ash. From Table 3 it can also be seen that the unburned carbon content of the whole Blacksville fly ash is about $3.6 \%$, while the PRB fly ash contained less than $0.1 \%$. The unburned carbon in the Blacksville fly ash was highly concentrated (factor of 10) in the nonmagnetic fraction of the first cyclone catch.

Table 3. Results of Total Surface Area and Unburned Carbon Measurements for the Blacksville and PRB Fly Ash Samples.

\begin{tabular}{|l|c|c|}
\hline Sample & BET Surface Area $\left(\mathbf{m}^{\mathbf{2}} / \mathbf{g r a m}\right)$ & Unburned Carbon (\%) \\
\hline Blacksville Ash & 3.6 \\
$\quad$ Whole & 3.4 & \\
Cyclone 1 & 1.5 & 0.39 \\
$\quad$ Strong Magnetic & 4.8 & 3.9 \\
$\quad$ Nonmagnetic & 7.2 & 0.13 \\
Cyclone 2 (all nonmag.) & & \\
PRB Ash & 1.5 & 0.08 \\
Whole & 1.7 & not determined \\
Cyclone 1 (all nonmag.) & 2.0 & not determined \\
Cyclone 2 (all nonmag.) & & \\
\hline
\end{tabular}

\section{$\underline{\text { Data Uncertainties in Bench Scale Tests }}$}

There are a variety of uncertainties that must be kept in mind when viewing the data obtained while using fly ash in simulated flue gas streams. The certification on the $\mathrm{Hg}$ permeation tube is only accurate to within $\pm 3 \%$ at the specified temperature. Also, although the water bath that is used to heat the U-tube containing the permeation tube has a precision of about $0.1^{\circ} \mathrm{C}$, the temperature of the water bath appears to be accurate to only within $0.5^{\circ} \mathrm{C}$. This, in itself, adds an uncertainty of roughly $\pm 5 \%$ in the $\mathrm{Hg}$ emission rate in view of potential day-today variations in the water temperature and other factors. Other uncertainties in this work are 1) variations in gas concentrations due to metering errors, 2) analytical errors, which are on the order of $2-3 \%, 3$ ) possible variations in the uniformity of fly ash loadings from sample to sample, and 4) sample preparation issues associated with the workup of the impinger solutions prior to 
analysis. Despite these issues, the percentages of oxidized and elemental $\mathrm{Hg}$ collected in the Ontario Hydro impingers were generally (95\% of all cases) repeatable to within $2 \%$ (absolute) of the mean for a given set of experimental conditions. This is considered to be excellent in view of the numerous potential sources of error in this work and the known difficulties involved with the Ontario Hydro method. Because only major changes in $\mathrm{Hg}$ speciation are being sought in this work, the uncertainties mentioned above do not affect any of the conclusions drawn.

Another uncertainty that was considered is the possibility that significant amounts of $\mathrm{Hg}$ could be sorbed onto the ash during testing, and that the degree of sorption may not be consistent as experimental variables were altered. Total $\mathrm{Hg}$ recoveries generally ( $85 \%$ of all cases) ranged from 85 to $110 \%$. Spot checks (using chemical leaching with subsequent analysis by cold vapor atomic absorption) on the $\mathrm{Hg}$ content of the fly ashes exposed to $\mathrm{Hg}$ in our tests indicated that there was little (less than $1 \%$ of the total $\mathrm{Hg}$ ) or no $\mathrm{Hg}$ retention by the fly ash.

\section{$\underline{\text { Results from Bench Scale Testing }}$}

To simplify and clarify data presentation, only the mean values for the percentages of oxidized $\mathrm{Hg}$ are presented in this paper. Since the percentages were determined on the $\mathrm{Hg}$ collected in solution, the remaining $\mathrm{Hg}$ is all elemental and need not be reported in the tables. Results obtained with unsized and sized fly ash samples are discussed below.

Unsized Fly Ash. Results of the tests at $120^{\circ}$ and $180^{\circ} \mathrm{C}$ using the baseline and full gas blends with unsized fly ash samples are shown in Table 4. Results of the statistical analyses for those data are shown in Tables 5 and 6 . In viewing all of the data in Table 4, it is evident that substantial amounts (i.e., more than 50\%) of $\mathrm{Hg}$ oxidation were not observed. No $\mathrm{Hg}$ oxidation was observed when using the baseline blend, regardless of which ash or which temperature (120 versus $180^{\circ} \mathrm{C}$ ) was used. When using the full gas blend, there were hints of $\mathrm{Hg}$ oxidation even with blank (no ash) filters, but significant amounts of oxidation were observed only in the presence of fly ash. Thus, the most important factors were whether or not ash was present and whether the baseline blend or the full gas blend was used during testing. Based on the statistical analyses for Test Series 1 and 2 (see Table 2), the source of the ash also affected the level of $\mathrm{Hg}$ oxidation, but to a lesser extent. Also, there was an interaction between the source of the ash and the flue gas composition. Passing the simulated flue gas through Blacksville ash resulted in a greater degree of $\mathrm{Hg}$ oxidation than the PRB coal ash. Although the whole Blacksville fly ash appeared to be slightly more catalytic than the PRB fly ash, this may simply reflect surface area differences (higher for Blacksville fly ash) between the samples rather than to something inherently unique (e.g., surface chemistry) with a particular fly ash sample. These observations are in agreement with the growing body of data associated with Blacksville fly ash. Specifically, although the majority of the $\mathrm{Hg}$ in actual flue gases from the combustion of Blacksville coal appears to be in the oxidized form, the majority of the $\mathrm{Hg}$ in simulated combustion streams exposed to Blacksville fly ash is in the elemental form. Temperature was not a statistically important factor for the two temperatures tested based on Test Series 1, and was only marginally significant based on statistical results from Test Series 2. 
Table 4. Results Obtained Using the Baseline and Full Blends with PRB and Blacksville Fly Ash*.

\begin{tabular}{|l|c|}
\hline \multicolumn{1}{|c|}{ Conditions } & Oxidized Hg (\%) \\
\hline Baseline Blend, PRB Ash, $120^{\circ} \mathrm{C}$ & 0 \\
Baseline Blend, PRB Ash, $180^{\circ} \mathrm{C}$ & 0 \\
\hline Baseline Blend, Blacksville Ash, $120^{\circ} \mathrm{C}$ & 0 \\
Baseline Blend, Blacksville Ash, $180^{\circ} \mathrm{C}$ & 0 \\
\hline Full Blend, Blank Filter, $120^{\circ} \mathrm{C}$ & $<1$ \\
Full Blend, Blank Filter, $180^{\circ} \mathrm{C}$ & $<1$ \\
\hline Full Blend, PRB Ash, $120^{\circ} \mathrm{C}$ & 10 \\
Full Blend, PRB Ash, $180^{\circ} \mathrm{C}$ & 4 \\
\hline Full Blend, Blacksville Ash, $120^{\circ} \mathrm{C}$ & 19 \\
Full Blend, Blacksville Ash, $180^{\circ} \mathrm{C}$ & 16 \\
\hline Full Blend, Magnetic Blacksville Ash, $180^{\circ} \mathrm{C}$ & 3 \\
Full Blend, Nonmagnetic Blacksville Ash, $180^{\circ} \mathrm{C}$ & 24 \\
\hline
\end{tabular}

* All tests were performed with the whole (unfractionated) fly ash samples except for the last two data entries, in which magnetic and nonmagnetic concentrates from the whole ash were used.

Table 5. Results of the Effects of Ash on Mercury Oxidation (Series 1).

\begin{tabular}{lllc}
\hline Variable & Effect & T- Value & $\begin{array}{l}\text { Probability of } \\
\text { Occurrence Due } \\
\text { To Chance* }\end{array}$ \\
\hline Ash Type & -10.00 & -3.04 & 0.012 \\
Ash Included & -23.50 & -3.73 & 0.004 \\
Temperature & 0.00 & 0.00 & 1.000 \\
Ash Type x Temp. & -1.50 & -0.46 & 0.658 \\
Ash Included x Temp. & 5.00 & -0.79 & 0.446 \\
\hline
\end{tabular}

* Expressed in percent as a decimal fraction, where 1.000 is $100 \%$. 
Table 6. Results of the Effects of Ash on Mercury Oxidation (Series 2).

\begin{tabular}{lllc}
\hline Variable & Effect & T- Value & $\begin{array}{c}\text { Probability of } \\
\text { Occurrence Due } \\
\text { To Chance* }\end{array}$ \\
\hline Ash Type & -4.500 & -5.81 & 0.000 \\
Gas Composition & -11.750 & -15.16 & 0.000 \\
Temperature & 2.000 & 2.58 & 0.026 \\
Ash Type x Gas Comp. & -4.500 & -5.81 & 0.000 \\
Ash Type x Temp. & -1.250 & -1.61 & 0.135 \\
Gas Comp. x Temp. & 2.000 & 2.58 & 0.026 \\
Ash Type x Gas Comp. x Temp. & -1.250 & -1.61 & 0.135 \\
\hline
\end{tabular}

* Expressed in percent as a decimal fraction, where 1.000 is $100 \%$.

For the magnetic and nonmagnetic concentrates from the unsized ash (see Table 4), it is interesting to note that the nonmagnetic phases actually resulted in substantially higher amounts of oxidized $\mathrm{Hg}$ than the magnetic phases. Results indicated that the nonmagnetic phases resulted in $24 \%$ of the $\mathrm{Hg}$ being oxidized, while $3 \%$ of the $\mathrm{Hg}$ was oxidized when using the magnetic ash. It has been suspected that the magnetic (iron-rich) phases in fly ash would be more catalytic than the nonmagnetic (aluminosilicate-rich) phases because of its mineralogy (predominantly iron oxides) and possibly because the magnetic phases tend to be enriched in transition metals that could serve as oxidation catalysts. However, under the experimental conditions employed, our results do not support this. Our results track well with the relative surface areas between the two fractions. Although not presented in Table 3, the surface area for the nonmagnetic ash was roughly four times that of the magnetic ash. Therefore, the larger amounts of oxidized $\mathrm{Hg}$ obtained while using the nonmagnetic ash may reflect the surface area differences between the magnetic and nonmagnetic fractions. Because of these surface area differences, caution must be exercised when drawing conclusions about the relative catalytic effects between the magnetic and nonmagnetic phases.

As previously noted, the goal of this project is to identify fly ash components responsible for the catalytic oxidation of elemental $\mathrm{Hg}$ in flue gas streams. Consequently, when viewing the data, we are looking for major differences in test results (i.e., percent of the total $\mathrm{Hg}$ that is oxidized) obtained under differing experimental conditions. Because major differences were not 
observed while using the full gas blend with either of the two fly ashes tested at $120^{\circ}$ and $180^{\circ} \mathrm{C}$, subsequent efforts, which involved using the full factorial design, focused on using only the Blacksville fly ash at the higher of the two testing temperatures.

Results from the full factorial design testing with the Blacksville fly ash at $180^{\circ} \mathrm{C}$ are shown in Table 7. Results of the statistical analyses for those data (Test Series 3) are shown in Table 8. For the whole fly ash samples, the greatest degree of oxidation was observed when $\mathrm{NO}_{2}$ was present with either $\mathrm{HCl}$ or $\mathrm{SO}_{2}$ and when $\mathrm{NO}$ was absent from the gas stream. The synergistic effect of $\mathrm{NO}_{2}$ and $\mathrm{HCl}$ can be seen. When $\mathrm{NO}_{2}$ and $\mathrm{HCl}$ were added to the baseline blend, the amount of $\mathrm{Hg}$ oxidized was much higher than that obtained when summing the amount of $\mathrm{Hg}$ oxidized during the addition of $\mathrm{HCl}$ alone and $\mathrm{NO}_{2}$ alone.

Another interesting observation is that, everything else being equal, the presence of $\mathrm{NO}$ actually appears to inhibit oxidation in the presence of other gases. For example, when only $\mathrm{NO}_{2}$ and $\mathrm{SO}_{2}$ were added, the amount of $\mathrm{Hg}$ oxidized was about $24 \%$. However, when $\mathrm{NO}$ was also added without changing the $\mathrm{NO}_{2}$ and $\mathrm{SO}_{2}$ concentrations (the $\mathrm{N}_{2}$ balance gas was decreased to compensate for the addition of each gas), the amount of $\mathrm{Hg}$ oxidized decreased to $4 \%$. Similar effects can be seen for the tests with $\mathrm{NO}_{2}+\mathrm{SO}_{2}+\mathrm{HCl}$ with and without the addition of NO. For emphasis, the amount of $\mathrm{Hg}$ oxidation observed in the absence and in the presence of $\mathrm{NO}$ for various gas mixtures is shown in Table 9. Thus, there is some evidence that the NO concentration may play a very important role in determining $\mathrm{Hg}$ speciation in flue gases from coal combustion systems.

Table 7. Results of Full Factorial Design Testing with the Blacksville Fly Ash at $180^{\circ} \mathrm{C}$.

\begin{tabular}{|l|c|}
\hline Gases Added to Baseline Blend* & Oxidized Hg (\%) \\
\hline $\mathrm{SO}_{2}$ & 0 \\
$\mathrm{NO}$ & 0 \\
$\mathrm{NO}_{2}$ & 13 \\
$\mathrm{HCl}$ & 4 \\
$\mathrm{HCl}+\mathrm{NO}_{2}$ & 26 \\
$\mathrm{HCl}+\mathrm{NO}$ & 8 \\
$\mathrm{HCl}+\mathrm{SO}_{2}$ & 2 \\
$\mathrm{NO}_{2}+\mathrm{SO}_{2}$ & 24 \\
$\mathrm{NO}_{2}+\mathrm{NO}$ & 4 \\
$\mathrm{NO}+\mathrm{SO}_{2}$ & 0 \\
$\mathrm{HCl}+\mathrm{NO}+\mathrm{NO}_{2}$ & 17 \\
$\mathrm{HCl}+\mathrm{NO}$ & $+\mathrm{SO}_{2}$ \\
$\mathrm{HCl}+\mathrm{NO}+\mathrm{SO}_{2}$ & 30 \\
$\mathrm{SO}_{2}+\mathrm{NO}+\mathrm{NO}_{2}$ & 4 \\
$\mathrm{SO}_{2}+\mathrm{NO}+\mathrm{NO}_{2}+\mathrm{HCl}$ & 4 \\
\hline
\end{tabular}

* Baseline Blend $=\mathrm{N}_{2}, \mathrm{O}_{2}, \mathrm{CO}, \mathrm{CO}_{2}$, and $\mathrm{H}_{2} \mathrm{O}$ 
Table 8. Results of the Effects of Ash on Mercury Oxidation (Series 3).

\begin{tabular}{|c|c|c|c|}
\hline Variable & Effect & T- Value & $\begin{array}{l}\text { Probability of } \\
\text { Occurrence Due } \\
\text { To Chance* }\end{array}$ \\
\hline $\mathrm{SO}_{2}$ & -0.979 & -2.85 & 0.000 \\
\hline NO & 5.271 & 15.33 & 0.000 \\
\hline $\mathrm{NO}_{2}$ & -14.396 & -41.87 & 0.000 \\
\hline $\mathrm{HCl}$ & -7.479 & -21.75 & 0.000 \\
\hline $\mathrm{SO}_{2}+\mathrm{NO}$ & 2.354 & 6.85 & 0.000 \\
\hline $\mathrm{SO}_{2}+\mathrm{NO}_{2}$ & -2.479 & -7.21 & 0.000 \\
\hline $\mathrm{SO}_{2}+\mathrm{HCl}$ & 1.854 & 5.39 & 0.000 \\
\hline $\mathrm{NO}+\mathrm{NO}_{2}$ & 7.271 & 21.15 & 0.000 \\
\hline $\mathrm{NO}+\mathrm{HCl}$ & -1.646 & -4.79 & 0.000 \\
\hline $\mathrm{NO}_{2}+\mathrm{HCl}$ & -2.979 & -8.66 & 0.000 \\
\hline $\mathrm{SO}_{2}+\mathrm{NO}+\mathrm{NO}_{2}$ & 1.854 & 5.39 & 0.000 \\
\hline $\mathrm{SO}_{2}+\mathrm{NO}+\mathrm{HCl}$ & -0.479 & -1.39 & 0.180 \\
\hline $\mathrm{SO}_{2}+\mathrm{NO}_{2}+\mathrm{HCl}$ & 0.354 & 1.03 & 0.316 \\
\hline $\mathrm{NO}+\mathrm{NO}_{2}+\mathrm{HCl}$ & 0.354 & 1.03 & 0.316 \\
\hline $\mathrm{SO}_{2}+\mathrm{NO}+\mathrm{NO}_{2}+\mathrm{HCl}$ & -0.979 & -2.85 & 0.010 \\
\hline
\end{tabular}

* Expressed in percent as a decimal fraction, where 1.000 is $100 \%$.

Table 9. Effects of Nitric Oxide on Hg Oxidation.

\begin{tabular}{|l|cc|}
\hline \multicolumn{1}{|c|}{ Gas Blend } & \multicolumn{2}{c|}{ Percent Oxidized Mercury } \\
\cline { 2 - 3 } & Without NO & With NO \\
\hline $\mathrm{NO}_{2}+\mathrm{SO}_{2}$ & 24 & 4 \\
\hline $\mathrm{NO}_{2}+\mathrm{SO}_{2}+\mathrm{HCl}$ & 30 & 16 \\
\hline $\mathrm{NO}_{2}+\mathrm{HCl}$ & 26 & 17 \\
\hline $\mathrm{NO}_{2}$ & 13 & 4 \\
\hline
\end{tabular}

From the statistical analysis of Test Series 3, which explores the composition of the flue gas in detail for the Blacksville fly ash, it is concluded that all factors and two-way interactions were statistically significant. Of the individual reactive gases that were added to the baseline blend, the most important factor was $\mathrm{NO}_{2}$. Next were $\mathrm{HCl}$ and $\mathrm{NO}$. However, the effect of $\mathrm{NO}$ depended on whether $\mathrm{NO}_{2}$ was present. Although the presence of $\mathrm{SO}_{2}$ was statistically significant as a main factor, it was more important in its interaction with other gas components. These results are in agreement with other work done by EERC. Based on these results this system is extremely complex. It appears that even four-factor interactions for these gases are 
significant. In view of the complexity of the gas interactions with fly ash, the difficulties in understanding the $\mathrm{Hg}$ chemistry in coal-derived flue gas is not surprising. This is particularly true in view of the fact that the simulated flue gas system is still very simple compared to actual flue gas streams.

Sized Fly Ash. Results of tests with the sized fly ash fractions and magnetic and nonmagnetic concentrates from those ash fractions are shown in Table 10. As noted earlier, these tests were performed at $180^{\circ} \mathrm{C}$ with $\mathrm{NO}_{2}, \mathrm{SO}_{2}$, and $\mathrm{HCl}$ added to the baseline blend. That gas blend was selected since it resulted in the greatest degree of $\mathrm{Hg}$ oxidation in the tests involving the full factorial design (see Table 7). It is interesting to note that, with this particular gas blend, the degree of oxidation observed between the magnetic and nonmagnetic concentrates from the first cyclone were very similar, even though the later had ten times the organic carbon content as the magnetic fraction (see Table 3). Therefore, the organic (unburned) carbon content does not appear to play a vital role in $\mathrm{Hg}$ oxidation chemistry based on these limited results.

It is also of interest to note that the nonmagnetic fraction was only slightly more catalytic than using the magnetic fraction in these tests. Thus, these results are substantially different from those obtained using the full gas blend with magnetic and nonmagnetic concentrates from the unsized fly ash (see Table 4), where the nonmagnetic phases appeared to be much more catalytic than the magnetic phases. This could be related to experimental differences between the two sets of data, including 1) differences in gas matrices used, and 2) differences in particle sizes used. The differences in the percent oxidized $\mathrm{Hg}$ shown in Table 10 tracked well with the respective surface areas of each ash fraction, although the magnitude of the differences in surface areas between ash fractions did not always produce changes of equal magnitude in the percent oxidized $\mathrm{Hg}$ formed.

Table 10. Results of Tests Using Sized Fly Ash and Magnetic and Nonmagnetic Ash from Those Size Fractions (Using Baseline Blend Plus $\mathrm{NO}_{2}, \mathrm{SO}_{2}$, and $\mathrm{HCl}$ ).

\begin{tabular}{|l|c|}
\hline Sample & Oxidized Hg (\%) \\
\hline Blacksville Ash & \\
Cyclone 1 & 22 \\
Magnetic & 28 \\
Nonmagnetic & 30 \\
Cyclone 2 (all nonmag.) & \\
\hline PRB Ash & 13 \\
Cyclone 1 (all nonmag.) & 20 \\
Cyclone 2 (all nonmag.) & \\
\hline
\end{tabular}


Results obtained with different Blacksville fly ash fractions (sized ash and magnetic and nonmagnetic concentrates from the sized ash) exposed to various gas blends at $180^{\circ} \mathrm{C}$ are shown in Figures 1 and 2. The gases noted in those figures were added to the baseline blend. As can be seen from Figure 1, the nonmagnetic phases in the first cyclone catch were always more catalytic than the magnetic phases in that cyclone catch. However, with the exception of the tests involving the addition of $\mathrm{NO}_{2}$ and $\mathrm{HCl}$ to the baseline blend, the differences observed between the magnetic and nonmagnetic phases were not substantial. When $\mathrm{NO}_{2}$ and $\mathrm{HCl}$ were added to the baseline blend, the amount of oxidized $\mathrm{Hg}$ was about four times higher when using the nonmagnetic phases versus the magnetic phases.

In Figure 2, the results obtained while using nonmagnetic phases from the first and second cyclone catches of the sized Blacksville fly ash are shown. In three of the four series of tests, more oxidation was observed when using the smaller particle size fraction. This is to be expected in view of surface area differences between the two size fractions. It is not known why that trend did not hold true when adding $\mathrm{NO}_{2}$ and $\mathrm{HCl}$ to the baseline blend. As noted earlier, the reproducibility was generally excellent for duplicate tests involving the Ontario Hydro Method for $\mathrm{Hg}$ speciation. It is interesting to note that for both Figures 1 and 2, the data obtained when adding $\mathrm{NO}_{2}$ and $\mathrm{HCl}$ to the baseline blend did not match the trends observed for the other gas blends within a given figure. Thus, that particular gas mixture is one to watch carefully in future tests.

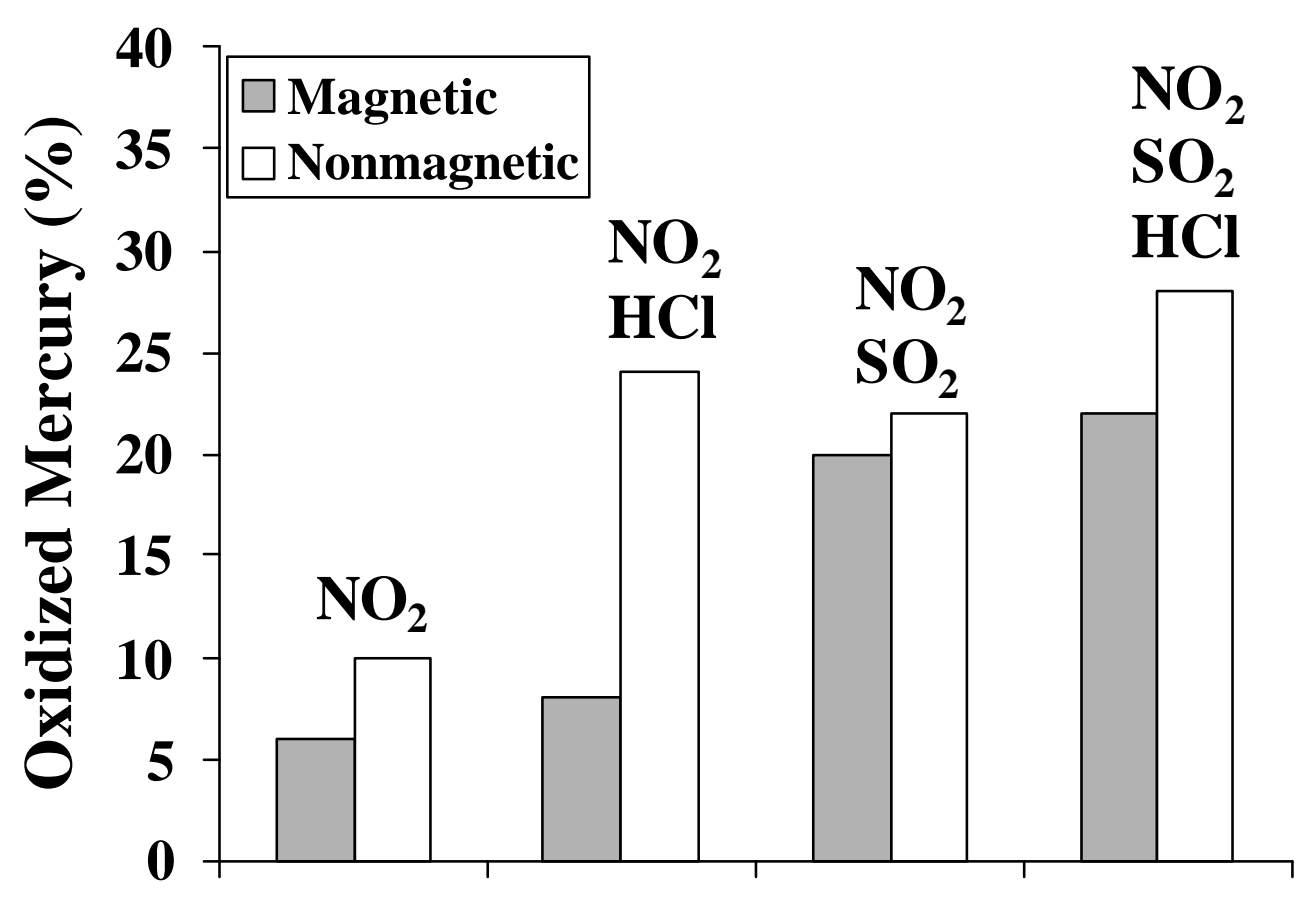

Figure 1. Comparison Between the Magnetic and Nonmagnetic Concentrates from the First Cyclone Catch using Blacksville Fly Ash. 


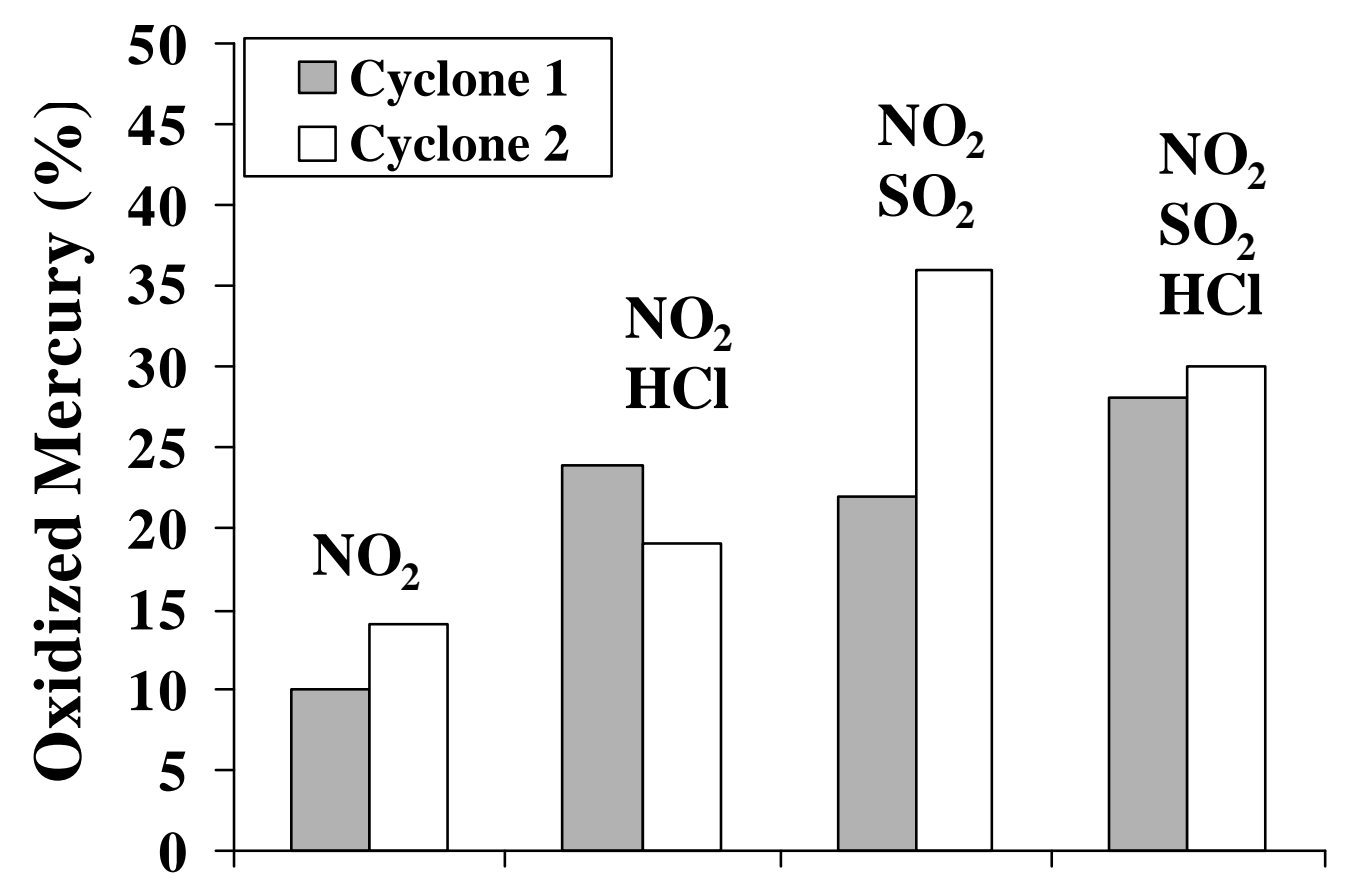

Figure 2. Comparison Between the Nonmagnetic Blacksville Fly Ash Fractions Collected in the First and Second Cyclones.

\section{CONCLUSIONS}

The two fly ash samples studied were chemically and mineralogically much different from one another, yet large differences in catalytic potential between those ashes were not observed. The gas matrix in actual flue gas streams may be more important than the ash composition, although the presence of fly ash does play in important role. Catalytic effects from different fly ashes may be largely attributable to differences in surface areas. In our bench scale testing, surface area effects may have been suppressed to some extent because of the short contact times. The $\mathrm{Hg}$ oxidation chemistry is very complex. When considering the diversity of fly ashes from different sources as well as the diversity in flue gas compositions from coal-fired utility boilers, it is clear that accurately predicting levels of different $\mathrm{Hg}$ species in flue gas streams will require extensive studies.

\section{FUTURE WORK}

A number of tests will be performed with the bench-scale setup using simulated flue gas streams whereby the ratios of $\mathrm{HCl}, \mathrm{NO}, \mathrm{NO}_{2}$, and $\mathrm{SO}_{2}$ will be varied and passed over Blacksville fly ash at $180^{\circ} \mathrm{C}$. This will provide important information on reaction mechanisms that are occurring in the presence of fly ash. In addition, the full gas blend will be used while varying the 
moisture content in order to determine the effects of that variable on the extent of $\mathrm{Hg}$ oxidation. Also, the University of Maryland - Eastern Shore (UMES) will perform tests on the reactivity of unburned carbon in the Blacksville fly ash. This is important because unburned carbon has been suspected as an oxidation catalyst in $\mathrm{Hg}$ oxidation chemistry.

Combustion tests will be performed with a $35 \mathrm{~kW}$ laboratory scale, down-flow combustor to study $\mathrm{Hg}$ chemistry using actual coal combustion streams. The combustor is equipped with new, state-of-the art gas analyzers for on-line continuous monitoring of $\mathrm{CO}, \mathrm{CO}_{2}, \mathrm{NO}, \mathrm{NO}_{2}$, and $\mathrm{O}_{2}$. In order to meet specific needs of this project, a number of modifications were made to the combustor, including adding ash and coal feeding systems and adding an additional section to the boiler to increase fuel residence time. The combustor is currently being equipped with two small pulse-jet baghouses containing Teflon filter membranes from W. L. Gore. In the combustion tests, ESP fly ash from one coal will be injected into filtered combustion gases generated by the other coal. This will be performed with both coals and both fly ash samples. These tests will help determine whether the ash plays a critical role in determining $\mathrm{Hg}$ speciation, or whether it is actually the flue gas matrix generated by a particular coal that is the primary factor affecting $\mathrm{Hg}$ speciation.

The Ontario Hydro Hg speciation method used to generate results thus far requires a high level of quality assurance/quality control, requires well trained personnel, provides no real-time data, and does not provide long-term results showing $\mathrm{Hg}$ emission variations. In view of these considerations, a continuous emission monitor (CEM) for $\mathrm{Hg}$ was obtained for use in this project and will be used for the coal combustion studies noted above as well as the bench-scale tests in which ratios of key gases will be varied. Specifically, a Tekran Model 2537A Mercury Vapor Analyzer will be coupled to a gas conditioning system built by the Energy and Environmental Research Center at the University of North Dakota (UND-EERC). Personnel at UND-EERC have provided ISU researchers with the necessary training on the operation and maintenance of the conditioner. The CEM and gas conditioning module are now fully integrated and ready for use to study $\mathrm{Hg}$ chemistry in coal combustion streams.

\section{REFERENCES}

1. EPRI Report Summary, "Mercury in the Environment -- A Research Update", EPRI RS107695, April 1997.

2. T. Brown, W. O'Dowd, R. Reuther, and D. Smith, "Control of Mercury Emissions from Coal-Fired Power Plants: A Preliminary Cost Assessment," presented at the Conf. on Air Quality: Mercury, Trace Elements, and Particulate Matter, McLean, VA, December 1-4, 1998.

3. R. Chang and D. Owens, "Developing Mercury Removal Methods for Power Plants," EPRI Journal, July/August, 1994, 46-49. 
4. D. L. Laudal, M. K. Heidt, K. C. Galbreath, B. R. Nott, and T. D. Brown, "State of the Art: Mercury Speciation Measurement in Coal Combustion Systems," presented at 90th Annual Meeting \& Exhibition of the Air and Waste Management Association, Toronto, Canada, June 8-13, 1997.

5. C. L. Senior et al., "A Fundamental Study of Mercury Partitioning in Coal Fired Power Plant Flue Gas," presented at 90th Annual Meeting \& Exhibition of the Air and Waste Management Association, Toronto, Canada, June 8-13, 1997.

6. S. J. Miller, E. S. Olson, G. E. Dunham, and R. K. Sharma, "Preparation Methods and Test Protocol for Mercury Sorbents," presented at 91st Annual Meeting of the Air and Waste Management Association, San Diego, CA, June 14-18, 1998.

7. G. M. Blythe, T. R. Carey, C. F. Richardson, R. G. Rhudy, and F. B. Meserole, "Enhanced Control of Mercury and Other HAPs by Innovative Modifications to Wet FGD Processes," presented at Advanced Coal-Based Power and Environmental Systems '98 Conference,"' Morgantown, WV, July 21-23, 1998.

8. S. J. Miller, G. E. Dunham, E. S. Olson, and T. D. Brown, "Mercury Sorbent Development for Coal-Fired Boilers," presented at the Conference on Air Quality: Mercury, Trace Elements, and Particulate Matter, McLean, VA, December 1-4, 1998.

9. B. Ghorishi, C. W. Lee, J. D. Kilgroe, B. K. Gullett, and C. B. Sedman, "Mercury Speciation and Control Technology Research at EPA," presented at the Conf. On Air Quality: Mercury, Trace Elements, and Particulate Matter, McLean, VA, December 1-4, 1998.

10. H. S. Huang, J. M. Wu, and C. D. Livengood, "Development of Dry Control Technology for Emissions of Mercury in Flue Gas," Hazard Waste Hazard. Mater. 13(1), 107-119, 1996.

11. R. Gleiser and K. Felsvang, "Mercury Emission Reduction Using Activated Carbon with Spray Dryer Flue Gas Desulfurization," in Proc. Am. Power Conf., (56)1, 1994, 452-457.

12. J. G. Noblett, Jr., F. B. Meserole, D. M. Seeger, and D. R. Owens, "Control of Air Toxics from Coal-Fired Power Plants Using FGD Technology," in Proc. Second Int. Conf. on Managing Hazardous Pollutants, Washington, D.C., July 13-15, 1993.

13. R. N. Sliger, D. J. Going, and J. C. Kramlich, "Chemical Kinetics of the High-Temperature Mercury Oxidation Mechanism," in Proc. Conf. On Air Quality: Mercury, Trace Elements, and Particulate Matter, McLean, VA, December 1-4, 1998.

14. C. D. Livengood and M. H. Mendelsohn, "Enhanced Control of Mercury Emissions through Modified Speciation," presented at 90th Annual Meeting \& Exhibition of the Air and Waste Management Association, Toronto, Canada, June 8-13, 1997. 
15. D. L. Laudal, M. K. Heidt, K. C. Galbreath, B. R. Nott, and T. D. Brown, "State of the Art: Mercury Speciation Measurement in Coal Combustion Systems," presented at 90th Annual Meeting \& Exhibition of the Air and Waste Management Association, Toronto, Canada, June 8-13, 1997.

16. U. S. Environmental Protection Agency, "Draft Ontario Hydro Method for Mercury in Flue Gas Generated from Coal-Fired Stationary Sources," September, 1999.

17. D. Laudal et al., "Mercury Measurement Research at the Energy and Environmental Research Center," presented at the Conf. on Source Emission and Ambient Air Monitoring of Mercury, Bloomington, MN, September 13-14, 1999.

\section{ACKNOWLEDGEMENTS}

We thank Matt DeVito of Consol, Inc. and John Cooper of AES Cayuga for their help in obtaining a sample of fly ash from the Pittsburgh No. 8 coal (Blacksville fly ash). We also thank Rob Chapman and other personnel at the City of Ames Power Plant for their help in obtaining a sample of fly ash from the Wyodak-Anderson coal. In addition, thanks are due to Maohong Fan for performing the total organic carbon analyses on the fly ash samples. This research was supported, in part, by DOE Grant DE-FG26-98FT4011. Additional financial support was provided by the Institute for Physical Research and Technology at Iowa State University. 